\title{
Editorials
}

\section{On editorial freedom: implications of the JAMA affair}

As this edition was going to press, the news broke that the executive vice president of the American Medical Association (AMA), E Ratcliffe Anderson, had sacked George Lundberg, who had edited the Fournal of the American Medical Association ( $(F A M A)$ for 17 years. Because we see this as of great importance for public health, we have taken the unusual decision to publish a joint editorial that will appear in the European Fournal of Public Health and the Fournal of Epidemiology and Community Health.

Most readers will, by now, be familiar with the circumstances surrounding Lundberg's dismissal. ${ }^{1}$ A paper reporting that, in 1991, 59\% of a sample of American college students would not consider orogenital contact as "having sex" had, after peer review, been fast tracked for publication, appearing the same week as the impeachment trial of President Clinton got underway in the United States Senate. The link was obvious, and indeed the paper's relevance to "recent presidential statements" was highlighted in a JAMA press release. Anderson argued that this action took the journal "into a major political debate that has nothing to do with science or medicine".

Although the fast tracking of the paper was cited as the cause for the sacking, it soon became clear that there were other, underlying, issues. These have been explored in detail by others, ${ }^{3}$ and will not be reviewed here, except to note that the AMA may have been feeling especially nervous about how such a paper would influence its support in Washington. The views expressed by the college students were in contrast with the case being made by the Republican House managers in the impeachment trial. And the AMA has increasingly been linked with the Republican Party, making large contributions to Republican congressional candidates in recent years. The AMA may also have felt a need to avoid further controversy in the wake of a hostile media reaction to a deal in which it had agreed to endorse a large corporation's products in return for royalty payments, later cancelling it at a cost of over $\$ 13$ million. ${ }^{4}$

The AMA's decision has unleashed a tide of condemnation among editors of medical journals and others. Many have drawn attention to Lundberg's achievements. A proactive editor, he focused attention through special issues on important public health issues, such as tobacco, violence, and obesity. He also worked closely with others to create an evidence base on which editors can base decisions about, for example, the peer review process. The almost universal view is that this decision has reflected extremely badly on the AMA and, at the time of writing, it is doubtful whether its senior management will be able to survive.

It is, of course, possible to see this as a purely domestic matter, of interest largely to the membership of the AMA. This would be wrong. There is a real danger that this action will send out a message to those in power, especially in those countries where democracy has a less secure foundation, that attacks on editorial freedom by those in positions of power are acceptable. One can easily imagine the argument that "if it is ok for the AMA then it is ok for us". And censorship is not always explicit. More insidious is the self censorship that leads editors and authors to shy away from difficult topics, with potentially disastrous consequences for health as dangerous policies go unchallenged. The former Soviet Union offers many examples. The inability to challenge the bizarre beliefs of Lysenko, in the 1930s and 1940s, had catastrophic effects on agricultural production, contributing to repeated episodes of famine. ${ }^{5}$

This is a particular threat to those publishing in the field of public health. As Ibsen's Dr Stockman discovered, ${ }^{6}$ public health action inevitably challenges vested interests and can make one deeply unpopular. Public health seeks to make the invisible visible. However, politicians do not always take kindly to those who draw attention to the otherwise unseen consequences of their policies. ${ }^{7}$

Sometimes, the challenge will be aimed directly at politicians, as when it highlights the health needs of minorities that they would prefer to ignore. ${ }^{8}$ More often it will be at those outside government, but with friends in high places. The most obvious example is the tobacco industry ${ }^{9}$ but public health professionals have faced strong opposition from groups as diverse as arms producers and swimming pool manufacturers. ${ }^{10}$

In many parts of the world, the freedom to challenge vested interests is now accepted by politicians as one of the features of a pluralist society and scientific journals are regarded as not just a provider of solutions but also as an essential check on the executive. ${ }^{11}$ However, there is no room for complacency. Totalitarian regimes have held power in some countries for much of this century and, in some, the transition to pluralist democracy remains insecure. Even in those countries where prior restraint on publication was abolished centuries ago, strict libel laws can make it very difficult to challenge powerful corporations.

It is for these reasons that, above all, those working in public health should be alert to any challenge to editorial freedom. Of course, like all freedoms, there must be limits. As the US Supreme Court has ruled, the constitutional right to free speech does not extend to shouting "Fire" in a crowded theatre. However, it is a freedom that should be limited with great care, and only after a full and free debate.

These events pose a threat to the credibility of JAMA that the AMA must now tackle. The rest of the scientific community has also a responsibility, to ensure that everyone understands that such actions are completely unacceptable.

MARTIN MCKEE

Editor, European fournal of Public Health CARLOS ALVAREZ-DARDET Editor, Fournal of Epidemiology and Community Health

\footnotetext{
Horton R. The sacking of JAMA. Lancet 1999;353:252-3.

. 3 Smith R. The sacking of Brother George. BMF 1999;318:2109.

4 Kassirer JP, Angell M. The high price of product endorsement. N Engl F Med 1997;337: 700

5 Soyfer VN. Lysenko and the tragedy of Soviet science (translated from the Russian by Gruliow L and Gruliow R). New Brunswick, NJ: Rutgers University Press, 1994

Ibsen H. A public enemy. In: Watts P (translator). Ghosts and other plays. London: Harmandsworth, 1974.

McKee M, Sassi F. Gambling with the nation's health? The social impact of the national lottery. BMf 1995;311:521-2.

McKee M. The health of gypsies. Lack of understanding exemplifies wider disregard of Europe. BMF 1997;315:1172-3.

9 Duncan N. The BMA's campaign against the tobacco industry. In: BMA. Smoking out the barons. London: BMA, 1986.

Chapman S, Lupton D. The fight for public health. London: BMJ, 1994

11 Sampson A. The new anatomy of Britain. London: Hodder and Stoughton, 1971.
} 